Research Article

\title{
Temperature Control Technology for Construction of Jinsha River Bridge
}

\author{
Hui-Wu Jin ${ }^{(D)},{ }^{1}$ Guo-An Wang, ${ }^{1}$ and Zhan-Ming Chen ${ }^{2}$ \\ ${ }^{1}$ School of Transportation Engineering, Jiangsu Vocational Institute of Architectural Technology, Xuzhou, Jiangsu 221116, China \\ ${ }^{2}$ Jiangyin Construction Engineering Group Co., Ltd., Jiangyin, Jiangsu 214400, China \\ Correspondence should be addressed to Hui-Wu Jin; 821748687@qq.com
}

Received 20 September 2021; Accepted 22 October 2021; Published 3 November 2021

Academic Editor: Gaofeng Song

Copyright (c) 2021 Hui-Wu Jin et al. This is an open access article distributed under the Creative Commons Attribution License, which permits unrestricted use, distribution, and reproduction in any medium, provided the original work is properly cited.

The key problem of mass concrete temperature control is to effectively control the maximum temperature inside concrete, the temperature difference between inside and outside concrete, and the temperature difference between surface and environment. The size of the main tower cap of No. 3 Jinsha River Bridge is $37 \mathrm{~m} \times 23.5 \mathrm{~m} \times 5.5 \mathrm{~m}$, and the cubic volume of concrete reaches $4782.3 \mathrm{~m}^{3}$, which is poured in two times. In order to ensure construction quality of mass concrete structure, prevent the large mass concrete temperature stress, through the numerical simulation of the temperature control and optimization scheme, by optimizing the mixture ratio design, reducing the temperature of concrete pouring into the mold, cooling water cycling, insulation keeping in good health and a series of measures to effectively achieve the control goal, and eliminating the temperature cracks. The measured data show that the maximum temperature inside concrete, the temperature difference between inside and outside, and the temperature difference between surface and environment are qualified, but the temperature difference control of cooling water inlet and outlet has hysteresis effect, and the temperature difference between inlet and outlet will be greater than $10^{\circ} \mathrm{C}$, which should be noticed.

\section{Introduction}

Concrete has been widely used in all kinds of buildings, such as bridges, dams, and other structures. In the construction of large bridges, especially bridges across rivers, seas, and valleys, the size records of concrete structures have been constantly refreshed. However, due to the poor thermal conductivity of concrete, a lot of heat that the cement hydration reaction produced is not easy to dissipate. The heat accumulation within structure causes the internal structure of concrete rapid heating up, the uneven temperature field both inside and outside the structure, and the temperature stress in the structure. Excessive temperature stress easily causes structural cracks affecting the structure durability. Structural cracks caused by temperature stress will have serious consequences on structural damage especially for mass concrete. According to the Construction Code for Mass Concrete (GB 50496-2018) [1,2], mass concrete with the minimum size of concrete structure entity not less than $1 \mathrm{~m}$, or concrete that is expected to cause harmful cracks due to temperature change and shrinkage caused by hydration of cementing materials in concrete, is regarded as mass concrete. Therefore, temperature control is an urgent problem to be solved in mass concrete construction, and reasonable and effective technical measures must be taken to deal with it properly. Domestic and foreign scholars and engineers have carried out a lot of research work on temperature control during the construction of mass concrete and obtained a lot of research results.

Wan et al. [3] studied the crack prevention construction technology of mass concrete for the main bridge cap of South Dongting Bridge and pointed out many technical measures: the optimized design of concrete cofferdam reduces the total quantity of heat of hydration, thinning layered casting thickness increases concrete cooling capacity, improving the heat dissipation efficiency of the internal and external heat, reducing temperature rise of concrete, controlling the temperature of concrete casting into the mold, lowering temperature peak of caps concrete, adopting the water storage curing meet the requirements of large volume 
concrete heat preservation and heat insulation method, and so on. Yuan et al. [4] used the measured temperature field of hydration heat in No. 0 block of a continuous box girder and established a cooling pipe water circulation model by using finite element analysis method under the condition that the noncooling pipe water circulation model was consistent with the measured temperature field and analyzed the cooling effect and crack control effect of the cooling pipe water circulation model. He et al. [5] analyzed the casting thickness effect on the internal temperature and stress of mass concrete and cooling water and and selected the suitable casting and temperature control scheme for Rongjiang Bridge project. Jin et al. [6,7] studied the concrete temperature field and stress field of concrete by simulating the concrete pouring process of the cap in a low-temperature environment, proposed the temperature control standard and measures, and verified the numerical analysis conclusion of the study based on the monitoring results of the temperature field. Qiao [8] put forward the measures when adding fly ash into the concrete and taking measures to reduce the temperature of concrete entering the mold and monitored the temperature of a large bridge cap in the construction. Yang et al. $[9,10]$ took targeted temperature control measures for the temperature control of the cap based on the field measured data and finite element calculation model, analyzed the concrete temperature of the cap, the steel stress, and the water temperature of the inlet and outlet of the cooling pipe, drew a conclusion that the temperature control measures for mass concrete are necessary and effective. Wang et al. [11] analyzed the actual anticracking effect of the temperature control different construction schemes and temperature control measures, such as the whole gating, layer pouring, cooling water pipe, and so on. Zhang et al. [12] obtained the specific cooling effect of spatial threedimensional cooling net on the basis of the gravity anchorage of a suspension bridge as the research object, the MIDAS/civil finite element software simulation of mass concrete construction is a three-dimensional network and only layout cooling pipe cooling, one-time casting thickness of singlelayer thickness and double-layer thickness of layered casting process, and comparative analysis of these four conditions of temperature field and temperature stress field. Li et al. [13] put forward the "curing" dynamic design method, with the mass concrete temperature control scheme design for main pier pile caps of a Yangtze River Bridge, calculation of big-volume concrete internal temperature field and stress field simulation, and developed the temperature control standard of harmful temperature crack and the corresponding temperature control measures according to the calculated results.

According to the theoretical calculation, the maximum internal temperature of concrete and the allowable stress corresponding to each age of concrete can be obtained, but the occurrence time of the maximum temperature and the change curve of temperature with time cannot be determined. The numerical simulation method can overcome the deficiency of theoretical calculation effectively, get the timehistory curve of concrete temperature and stress, and intuitively display the temperature field and stress field inside concrete at each time point. Midas software is well used to calculation of the temperature field. Boundary conditions and construction process simulation are the key problems, which are directly related to the accuracy of calculation results.

In this paper, the No. 3 main tower cap of Jinsha River Bridge is taken as the research object, and a series of temperature control measures, such as optimizing the mix ratio design, reducing the temperature of concrete pouring into the mold, cooling water circulation, heat preservation, and health preservation, are studied to explore the effective means to achieve the temperature control target effectively and eliminate temperature cracks; at the same time, the measured data and simulation data are compared and analyzed to provide reference for temperature control of mass concrete construction.

\section{Project Overview}

Jinsha River Bridge with the main bridge $340 m+72 m+48 m+32 m$ single-tower cable-stayed bridge, the starting pile number is $\mathrm{K} 96+279$, and the ending pile number is $\mathrm{K} 96+844$. The side spans of the superstructure are prestressed concrete box beams, and the middle spans are P-K steel box beams. The approach bridge adopts $2 \times 35 \mathrm{~m}$ composite beams. The substructure adopts box pier, door frame pier, column pier, column abutment, and the foundation is bored pile foundation. The concrete grade is C40, in which the cap size of No. 3 main tower is $37 \mathrm{~m} \times 23.5 \mathrm{~m} \times 5.5 \mathrm{~m}$, and the concrete square volume reaches $4782.3 \mathrm{~m}^{3}$, which is poured twice. The bridge layout is shown in Figure 1.

\section{Design of Temperature Control Scheme for Mass Concrete Cap}

3.1. Technical Route of Temperature Control Scheme. In order to ensure the construction quality of mass concrete structure and avoid the harmful temperature crack of mass concrete, it is necessary to accurately predict and analyze the temperature field and temperature stress of mass concrete. How to design a reasonable temperature control scheme and ensure that the change of temperature field inside concrete is in a safe and controllable range are considered; the general idea is as follows:

(1) The adiabatic temperature rise and peak temperature of concrete can be reduced through raw material selection and mix ratio test

(2) According to the theoretical calculation of temperature control and construction environmental conditions, choose the surface insulation measures suitable for the construction season, reduce the temperature difference between inside and outside of concrete, make the distribution of temperature field in concrete as uniform as possible, and reduce the temperature gradient

(3) Through the internal cooling water circulation system, reduce the internal temperature peak of concrete, control the internal cooling rate, real-time monitoring of temperature, and intelligent control according to the monitoring data 


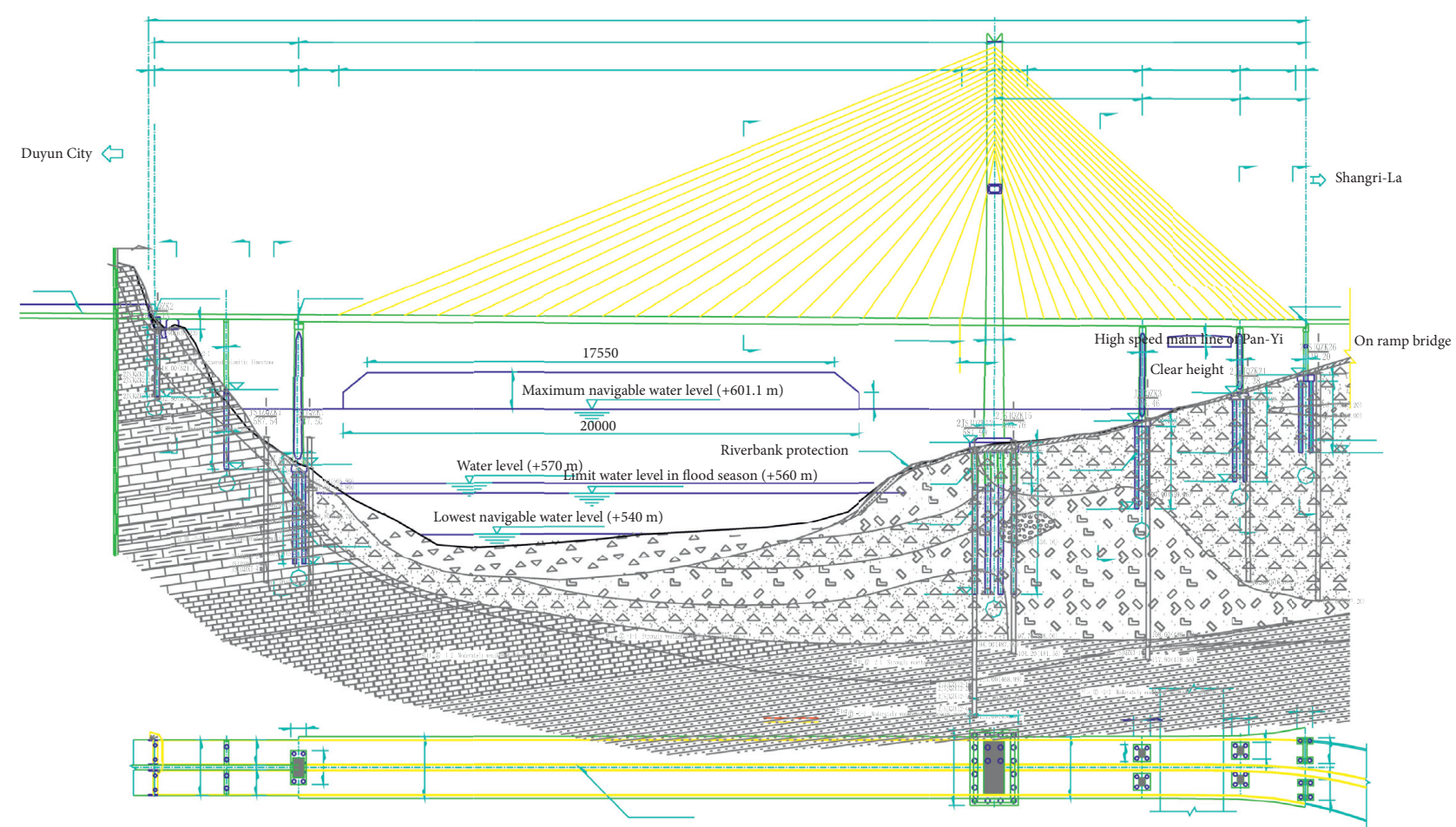

Figure 1: The layout of Jinsha River Bridge.

(4) Control the temperature difference between upper and lower layers, shorten the interlayer age difference as far as possible, and prevent the possible interlayer cracks

The specific process is shown in Figure 2.

\subsection{Selection of Concrete Raw Materials and Mixing Ratio}

\subsubsection{Selection Raw Materials of Concrete}

Cement: for cap C40 and tower base C50 concrete, in order to slow down the hydration reaction speed of cement and the growth rate of early strength of concrete, reduce the temperature appreciation of concrete; 42.5 ordinary Portland cement from Shuicheng Conch Panjiang Cement Company is selected.

Admixture: polycarboxylic acid high-efficiency water reducing agent with stable performance and high water reducing rate is preferred, which can effectively reduce the amount of cement per square meter of concrete, thus reducing the temperature rise of hydration heat of concrete. Through the adaptability test of water reducing agent and cement, the composition of water reducing agent is adjusted to ensure the effective initial setting time of concrete and meet the construction time of concrete pouring on-site.

Fly ash: in order to reduce the water consumption per unit of concrete, reduce the cement hydration heat of concrete and ensure the working performance of concrete; grade 1 fly ash is used.
Fine aggregate and coarse aggregate: the mud content of fine aggregate should be less than or equal to $3.0 \%$, fineness modulus $\geq 2.5$. Coarse aggregate is $5 \sim 25 \mathrm{~mm}$ continuous graded gravel with mud content $\leq 1.0 \%$ and should be washed in advance. The concrete is tested onsite and deducted from the total water consumption according to the measured water ratio of coarse aggregate and fine aggregate to ensure the accuracy of the actual water-cement ratio.

3.2.2. Concrete Mix Design. The raw materials and mixing ratio of C40 concrete for the main pier cap of Jinsha River Bridge are shown in Table 1.

3.3. Layout of Cooling Water Pipes. Cooling water pipe layout of cap and tower is shown in Figure 3. Cooling water pipes are all $40 \mathrm{~mm}$ in diameter with the horizontal spacing $1.0 \mathrm{~m}$. The thickness of the first cap is $3.0 \mathrm{~m}$ and the second one $2.5 \mathrm{~m}$, while the thickness of the tower is $2.0 \mathrm{~m}$. The height spacing between the cooling water pipe and the top surface is $0.5 \mathrm{~m}+2 \times 1.0 \mathrm{~m}+0.5 \mathrm{~m}, 0.75 \mathrm{~m}+1.0 \mathrm{~m}+0.75 \mathrm{~m}$, and $0.5 \mathrm{~m}+1.0 \mathrm{~m}+0.5 \mathrm{~m}$.

\section{Numerical Simulation of Temperature Control}

\subsection{Calculation Parameters and Calculation Model}

4.1.1. Thermal Parameters and Mechanical Parameters. The values of thermal and mechanical parameters of concrete for cap C40 and tower C50 are shown in Table 2. The 


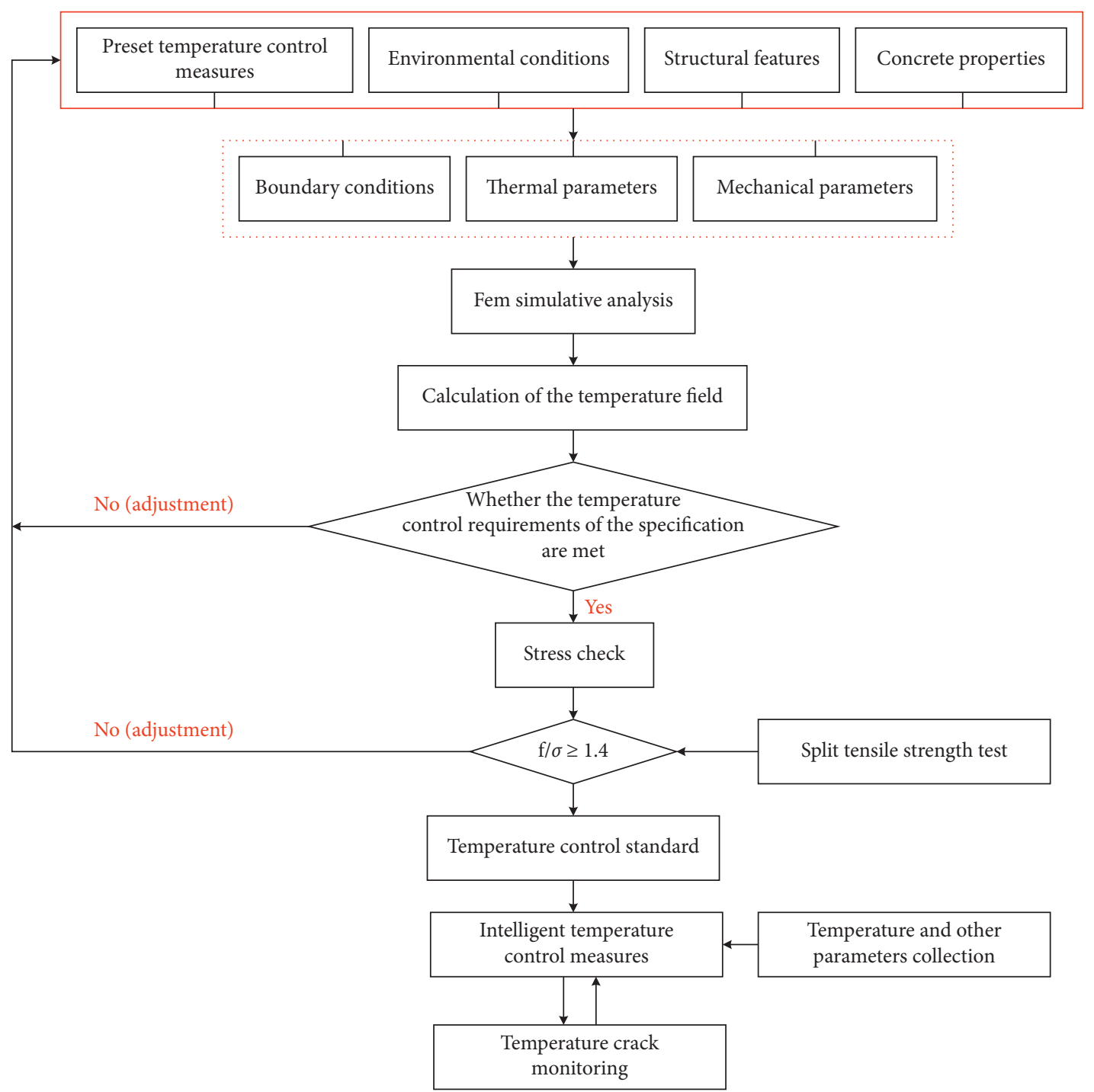

FIgURE 2: Temperature control flowchart.

TABLE 1: The lithology parameters of the 3D model.

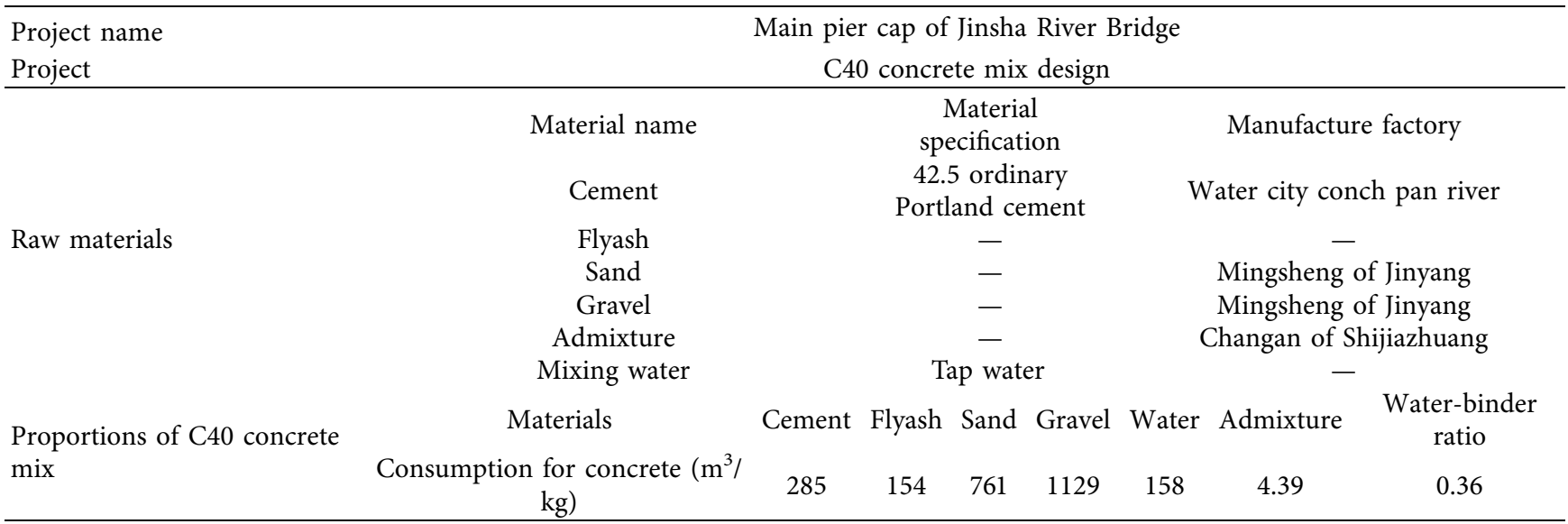




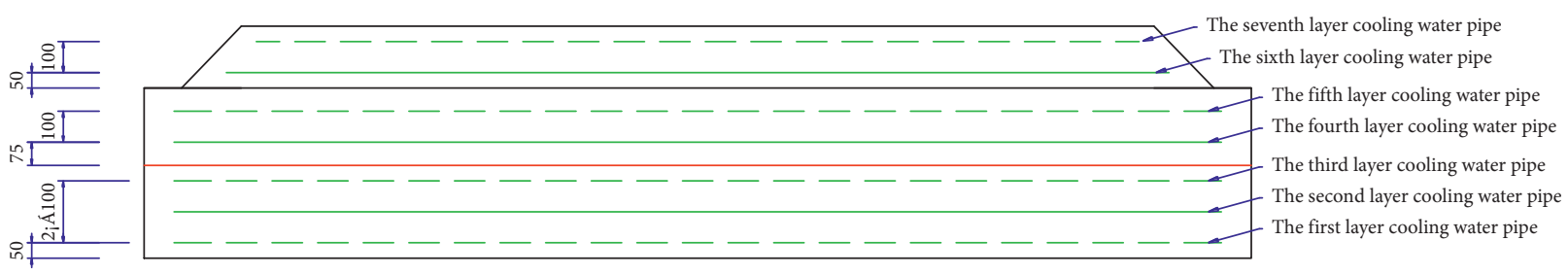

(a)
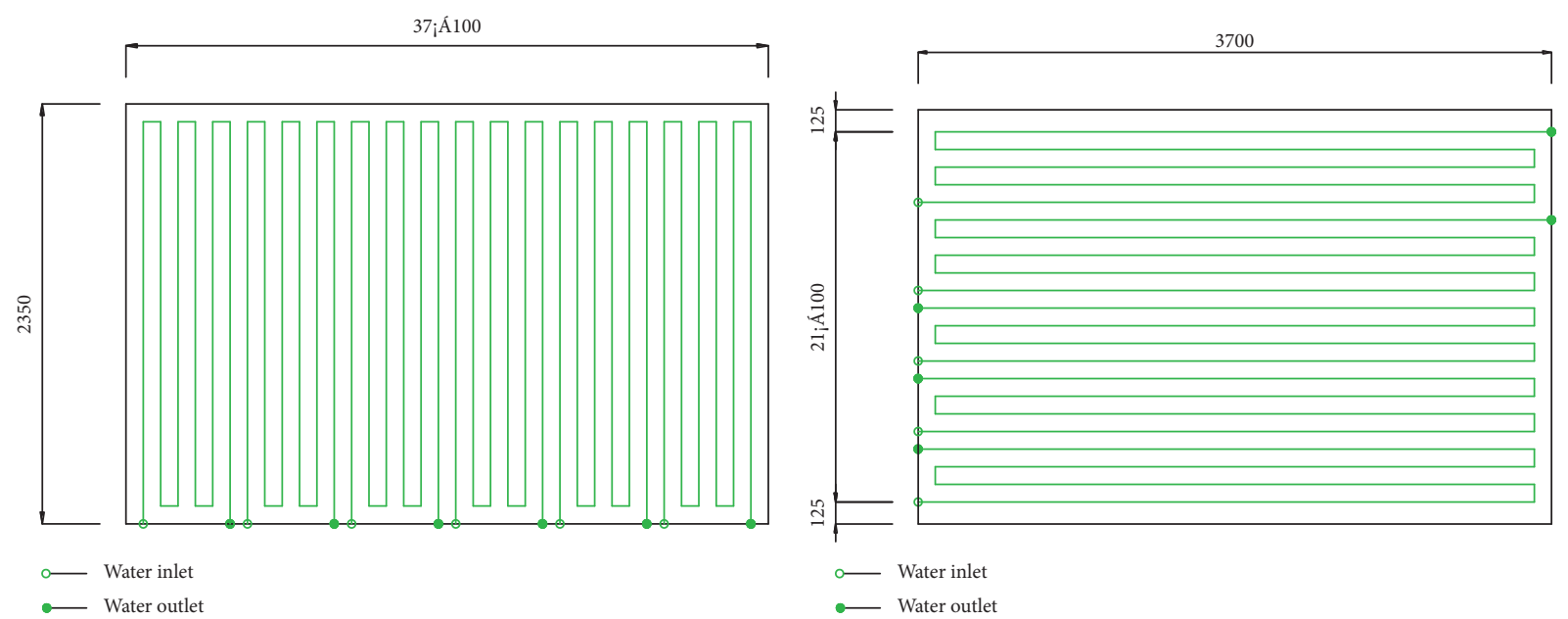

(b)
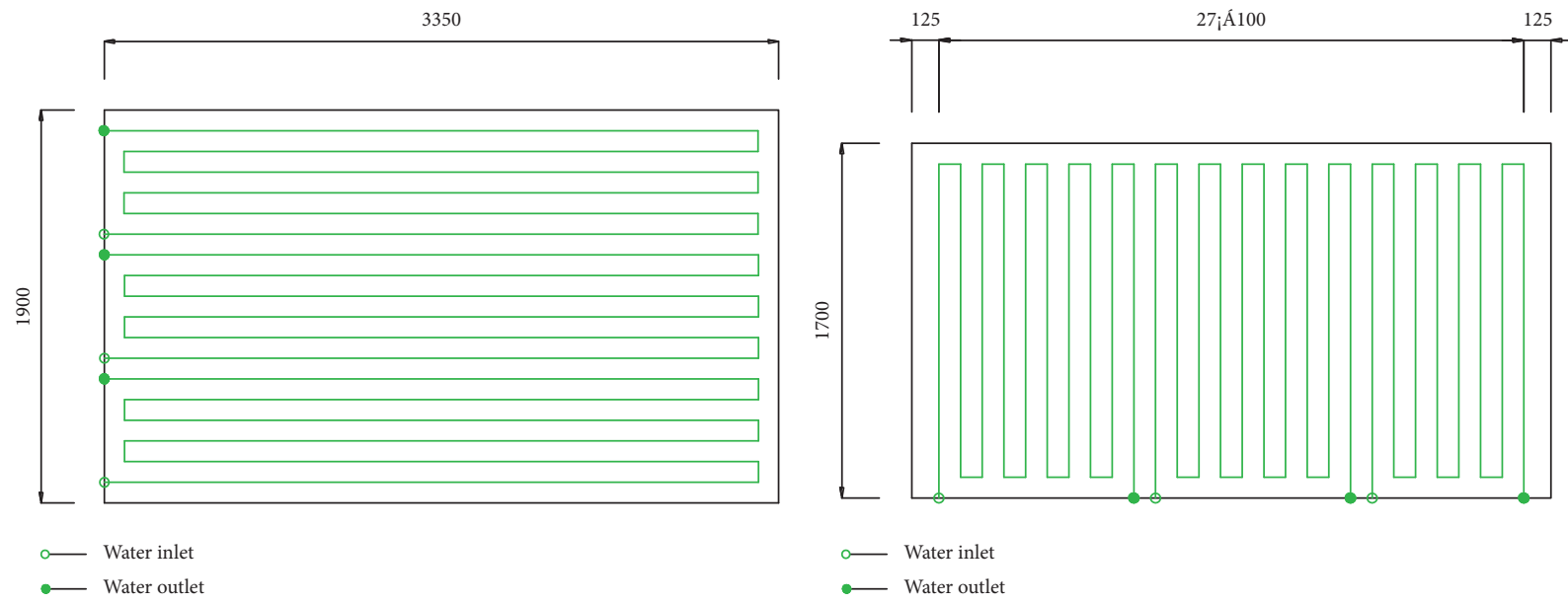

(c)

Figure 3: Cooling water pipe layout of cap and tower. (a) Elevation layout of cooling water pipes for cap and tower. (b) Cooling water pipe layout of cap. (c) Tower cooling water pipe layout.

TABLE 2: Summary of calculation parameters of cap concrete.

\begin{tabular}{lc}
\hline Physical properties & Silicate concrete \\
\hline Density $\left(\mathrm{kg} / \mathrm{m}^{3}\right)$ & 2491 \\
Coefficient of linear expansion $(1 / \mathrm{T})$ & $1 \times 10^{-5}$ \\
Poisson's ratio & 0.2 \\
Specific heat capacity $\left(\mathrm{kJ} /\left(\mathrm{kg}{ }^{\circ} \mathrm{C}\right)\right)$ & 0.96 \\
Pyroconductivity $(\mathrm{kJ} /(\mathrm{m} \cdot \mathrm{hr} \cdot \mathrm{T}))$ & 10.6 \\
Construction season & $3 \sim 5$ months \\
Average temperature during construction $\left({ }^{\circ} \mathrm{C}\right)$ & $22 \sim 28$ \\
Temperature of concrete entering mold $\left({ }^{\circ} \mathrm{C}\right)$ & $24 \sim 26$ \\
Adiabatic temperature rise $\left({ }^{\circ} \mathrm{C}\right)$ & $40 / 46$ \\
\hline
\end{tabular}

adiabatic temperature of ordinary Portland cement is the actual value (modified according to the temperature peak measured by No. 8 cap).

The mechanical parameters of concrete, for Portland cement concrete mix ratio, used the standard value. Concrete shrinkage and creep is calculated according to "Code for Design of Highway Reinforced Concrete and Prestressed Concrete Bridges" JTG D62-2015 in Midas/Civil. Ambient temperature is selected according to the temperature and casting temperature of concrete, and the preliminary selected ambient temperature is calculated to be $24^{\circ} \mathrm{C}$. In this calculation, the temperature of concrete entering mold is 
temporarily set at $24^{\circ} \mathrm{C} \sim 26^{\circ} \mathrm{C}$. In the construction process of cap and tower, the temperature control is calculated according to the actual casting temperature of concrete. The water temperature of the cooling pipe shall be considered as the river water, the river water temperature shall be $24^{\circ} \mathrm{C}$, and the flow shall be $3 \mathrm{~m}^{3} / \mathrm{h}$ in the heating stage and $1.0 \mathrm{~m}^{3} / \mathrm{h}$ in the cooling stage. In the process of temperature control, the inlet flow rate or inlet temperature should be adjusted according to the inlet temperature of cooling water and the monitoring of the internal temperature field of the cap tower.

4.1.2. Boundary Conditions. The 3D models in Figures 4 and 5 are established by MIDAS/civil finite element software.

(1) Convective Boundary. The insulation measures proposed for the top surface of the cap and tower are as follows: the first layer of plastic film + the second layer of geotextile + the third layer of rain cloth, and its equivalent heat transfer coefficient is $20 \mathrm{~kJ} /\left(\mathrm{h} \cdot{ }^{\circ} \mathrm{C}\right)$; the side of the cap is as follows: the first layer of geotextile + the second layer of rain cloth, and its equivalent heat transfer coefficient is $15 \mathrm{~kJ} /\left(\mathrm{h} \cdot{ }^{\circ} \mathrm{C}\right)$. In the actual construction, the insulation measures can be adjusted according to the actual environmental conditions and the measured temperature field.

(2) Constraint Boundary. Consolidation is adopted at the bottom of cushion of cap and tower. In accordance with the sequence of pouring and construction, the 1 2 layers of the cap are activated successively, and the actual age difference is considered for simulation calculation [14-16].

(3) Pouring Interval. The pouring interval is 10 days. It should be shortened as far as possible in the actual construction $[17,18]$.

\subsection{Calculation Results of Temperature Control}

4.2.1. Temperature Simulation Results. According to the relevant parameters of Portland cement concrete mix ratio, the overall calculation results of cap and tower temperature are shown in Table 3.

According to the results of temperature calculation, the peak temperature of the first layer-concrete of the cap is $54.1^{\circ} \mathrm{C}$ under the condition of $24^{\circ} \mathrm{C}$ of the temperature of concrete entering mold, and the temperature difference of the inner surface is less than $20^{\circ} \mathrm{C}$. Figure 6 shows the calculation results of maximum temperature field, and Figure 7 shows the temperature time-history curve.

The peak temperature of the second-layer concrete of the cap is $55.4^{\circ} \mathrm{C}$ under the condition of $24^{\circ} \mathrm{C}$ the temperature of concrete entering mold, and the temperature difference between inside and outside surface is less than $20^{\circ} \mathrm{C}$. Figure 8 shows the calculation results of the maximum temperature field, and Figure 9 shows the temperature time-history curve.

The peak temperature of the tower base concrete is $61.8^{\circ} \mathrm{C}$ under the condition of $26^{\circ} \mathrm{C}$ of the concrete entering

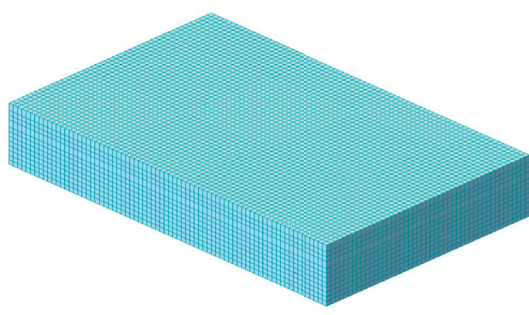

FIgURE 4: Cap model drawing.

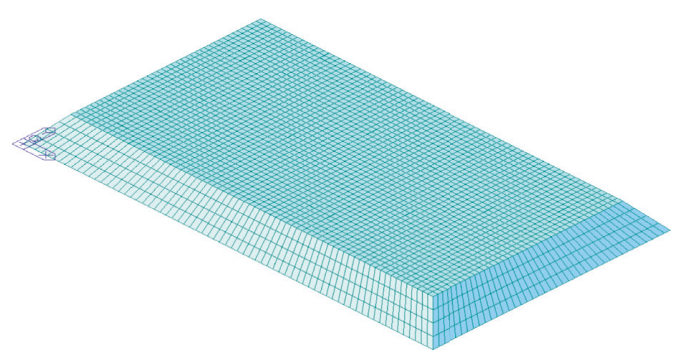

Figure 5: Tower base model diagram.

mold, and the temperature difference between inside and outside surface is less than $20^{\circ} \mathrm{C}$. Figure 10 shows the calculation results of the maximum temperature field, and Figure 11 shows the temperature time-history curve.

4.2.2. Stress Simulation Results. The overall stress calculation results of cap and tower base are shown in Table 4.

In the process of temperature change of concrete, the general change law of stress is as follows: in the stage of temperature rise, the surface tensile stress is the largest around the temperature peak time inside concrete; in the cooling stage, the internal stress gradually changes from compressive stress to tensile stress.

According to the stress calculation results, the maximum principal tensile stress of the first layer concrete of cap is between $1.33 \mathrm{MPa}$ and $2.02 \mathrm{MPa}$. The calculation results of the maximum principal tensile stress distribution are shown in Figure 12, and the stress time-history curve is shown in Figure 13.

The maximum principal tensile stress of the second layer concrete of cap is between $1.86 \mathrm{MPa}$ and $2.01 \mathrm{MPa}$. The calculation results of the maximum principal tensile stress distribution are shown in Figure 14, and the stress timehistory curve is shown in Figure 15.

The maximum principal tensile stress of tower concrete is between $1.77 \mathrm{MPa}$ and $2.29 \mathrm{MPa}$. The calculation results of the maximum principal tensile stress distribution are shown in Figure 16, and the stress time-history curve is shown in Figure 17 (SIG-maximum principal tensile stress).

\subsubsection{Numerical Simulation Conclusion}

(i) When the temperature of concrete entering mold is $24^{\circ} \mathrm{C} \sim 26^{\circ} \mathrm{C}$, the theoretical peak temperature of the concrete in each layer of cap and tower is $54.1^{\circ} \mathrm{C} \sim 61.8^{\circ} \mathrm{C}$. 
TABLE 3: Temperature calculation results.

\begin{tabular}{|c|c|c|c|c|c|c|}
\hline Position & Layer & $\begin{array}{c}\text { Temperature of } \\
\text { casting concrete }\left({ }^{\circ} \mathrm{C}\right)\end{array}$ & $\begin{array}{c}\text { Peak } \\
\text { temperature } \\
\left({ }^{\circ} \mathrm{C}\right) \\
\end{array}$ & $\begin{array}{c}\text { Time of peak } \\
\text { temperature }(\mathrm{h})\end{array}$ & $\begin{array}{c}\text { Temperature rise } \\
\text { value }\left({ }^{\circ} \mathrm{C}\right)\end{array}$ & $\begin{array}{c}\text { Temperature difference } \\
\text { between inside and outside } \\
\left({ }^{\circ} \mathrm{C}\right)\end{array}$ \\
\hline \multirow{2}{*}{ Cap } & $\begin{array}{c}\text { First-layer } \\
\text { concrete }\end{array}$ & 24 & 54.1 & 48 & 30.1 & 16.1 \\
\hline & $\begin{array}{c}\text { Second-layer } \\
\text { concrete }\end{array}$ & 24 & 55.4 & 48 & 31.4 & 17.4 \\
\hline $\begin{array}{l}\text { Tower } \\
\text { base }\end{array}$ & $\begin{array}{c}\text { First-layer } \\
\text { concrete }\end{array}$ & 26 & 61.8 & 48 & 35.8 & 18.5 \\
\hline
\end{tabular}

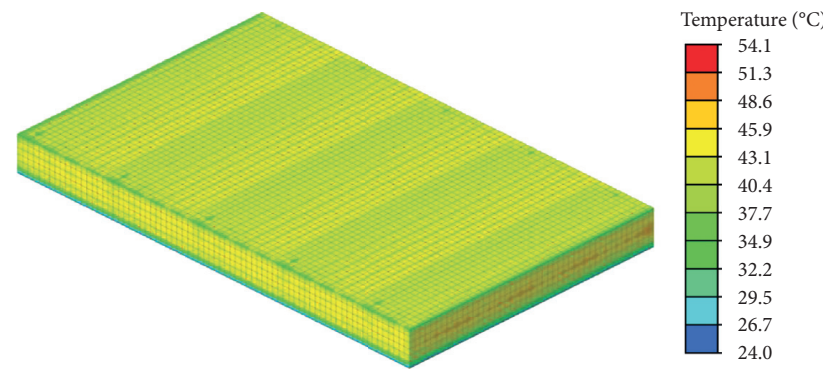

Figure 6: Distribution of the maximum temperature field on the first floor of cap (unit: ${ }^{\circ} \mathrm{C}$ ).

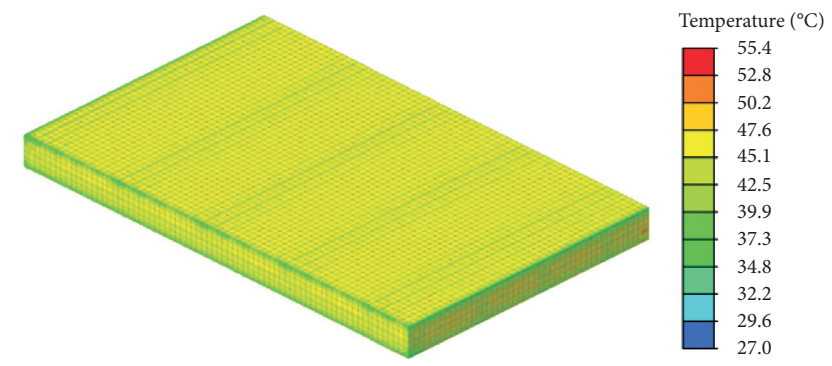

Figure 7: Time-history curve of concrete temperature in the first layer of cap.

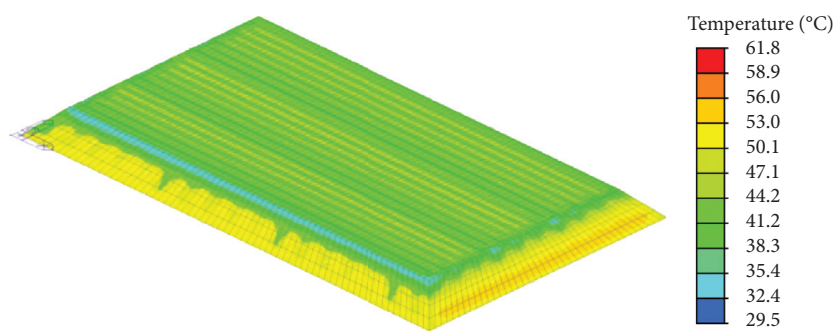

Figure 8: Distribution of maximum temperature field on the second floor of cap (unit: ${ }^{\circ} \mathrm{C}$ ).

(ii) According to the stress calculation results, the theoretical principal tensile stress of each layer of concrete is $1.86 \mathrm{MPa} 2.29 \mathrm{MPa}$ during the heating period, and 1.33 MPa 2.01 MPa after the cooling stage at the temperature of $24^{\circ} \mathrm{C} \sim 26^{\circ} \mathrm{C}$. The maximum principal tensile stress of each layer of concrete is less than the allowable stress in the heating and cooling stages, which meets the relevant requirements.

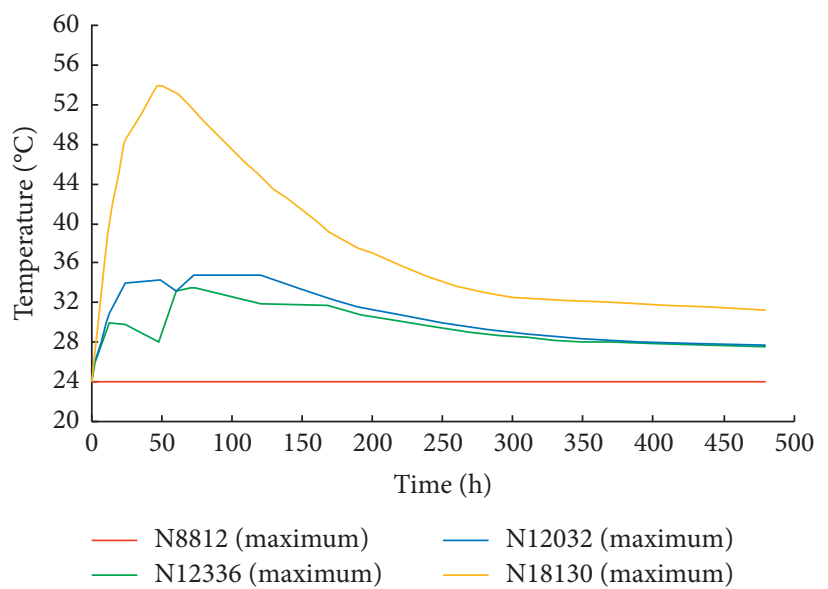

FIgURE 9: Time-history curve of concrete temperature of the second layer of cap.

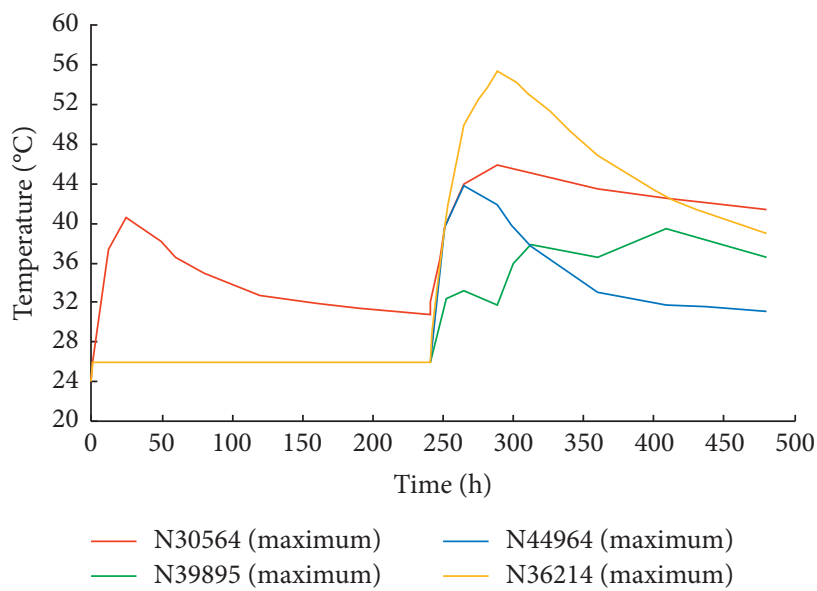

Figure 10: Distribution of the maximum temperature field of the tower (unit: ${ }^{\circ} \mathrm{C}$ ).

(iii) In the construction process, the temperature of concrete entering mold should be reduced as far as possible to reduce the temperature peak, to reduce the total temperature contraction deformation in the cooling stage. At the same time, pay attention to heat preservation in the maintenance process of the cap, reduce the temperature difference between inside and outside. 


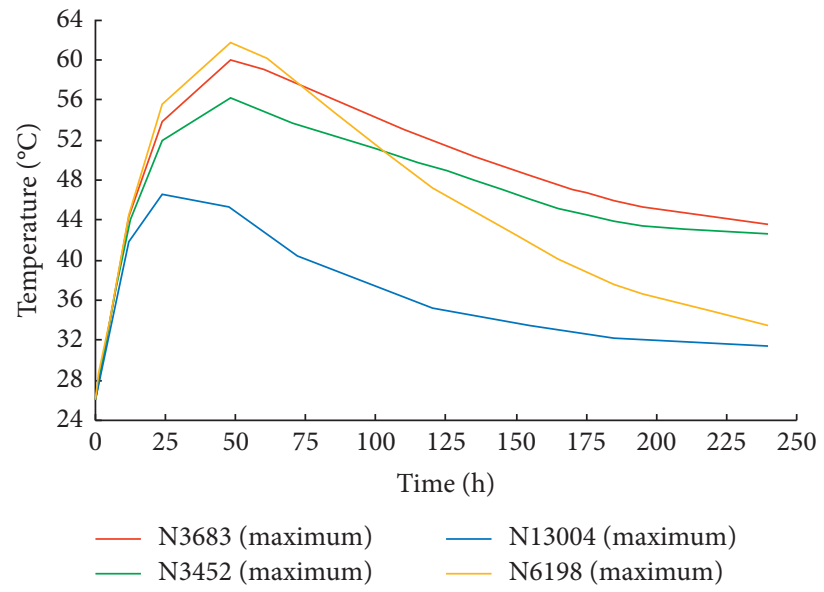

FIGURE 11: Concrete temperature time-history curve of tower.

TABLE 4: Stress calculation results.

\begin{tabular}{|c|c|c|c|c|c|c|c|c|c|}
\hline \multirow[b]{2}{*}{ Position } & \multirow[b]{2}{*}{ Layer } & \multicolumn{4}{|c|}{ Maximum principal tensile stress at heating stage } & \multicolumn{4}{|c|}{ Maximum principal tensile stress at cooling stage } \\
\hline & & $\begin{array}{c}\text { Stress value } \\
(\mathrm{MPa})\end{array}$ & $\begin{array}{l}\text { Concrete } \\
\text { age }(\mathrm{d})\end{array}$ & $\begin{array}{c}\text { Allowable } \\
\text { stress (MPa) }\end{array}$ & $\begin{array}{l}\text { Safety } \\
\text { factor }\end{array}$ & $\begin{array}{c}\text { Stress value } \\
(\mathrm{MPa})\end{array}$ & $\begin{array}{c}\text { Concrete } \\
\text { age }(\mathrm{d})\end{array}$ & $\begin{array}{c}\text { Allowable } \\
\text { stress (MPa) }\end{array}$ & $\begin{array}{l}\text { Safety } \\
\text { factor }\end{array}$ \\
\hline \multirow{2}{*}{ Cap } & $\begin{array}{l}\text { First-layer } \\
\text { concrete }\end{array}$ & 2.02 & 2.5 & 2.44 & 1.21 & 1.33 & 10 & 3.16 & 2.38 \\
\hline & $\begin{array}{l}\text { Second-layer } \\
\text { concrete }\end{array}$ & 1.86 & 2.5 & 2.44 & 1.31 & 2.01 & 10 & 3.16 & 1.57 \\
\hline $\begin{array}{l}\text { Tower } \\
\text { base }\end{array}$ & $\begin{array}{l}\text { First-layer } \\
\text { concrete }\end{array}$ & 2.29 & 2.5 & 2.71 & 1.18 & 1.77 & 10 & 3.45 & 1.95 \\
\hline
\end{tabular}

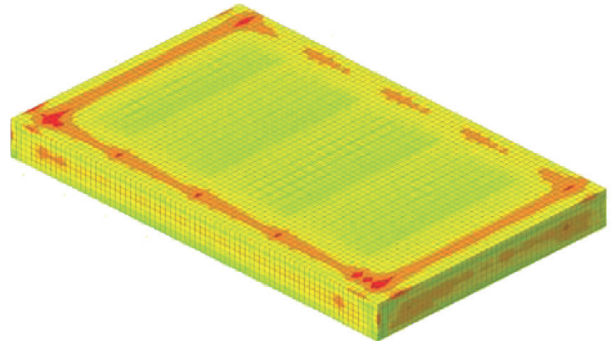

(a)

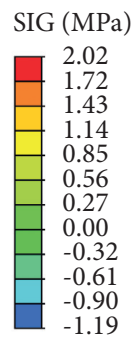

$-1.19$
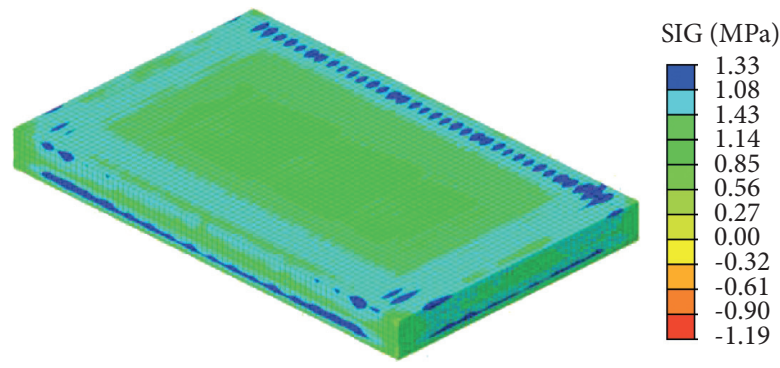

(b)

Figure 12: Cloud diagram of main tensile stress in the first layer of cap (unit: MPa). (a) Heating stage. (b) Cooling stage.

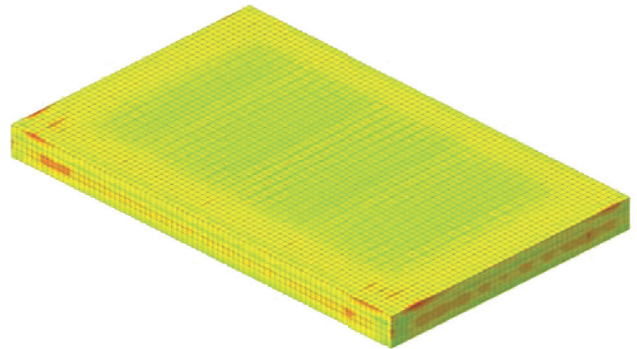

(a)

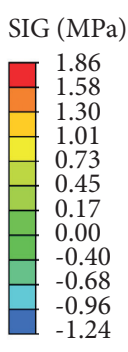

$-1.24$

FIGURE 13: Time-history curve of main tensile stress in the first layer of cap.

(iv) Try to reduce the construction interval between each layer of cap and tower base, so as to reduce the constraint between each layer of concrete. In order to avoid interlayer cracks caused by excessive binding force of the first layer concrete on the second layer, the temperature difference between the two layers of the cap must be controlled, so the interlayer age difference should be reduced as far as 


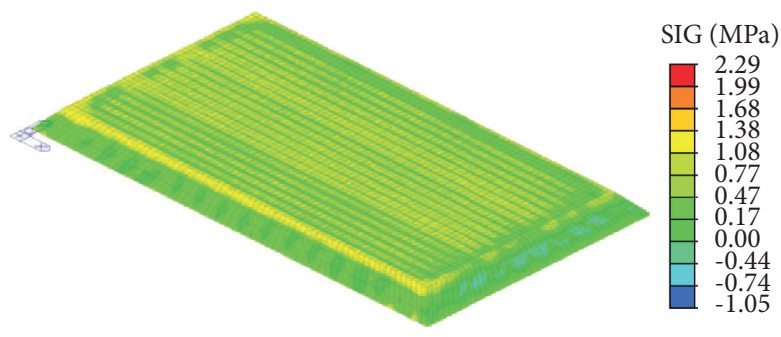

(a)

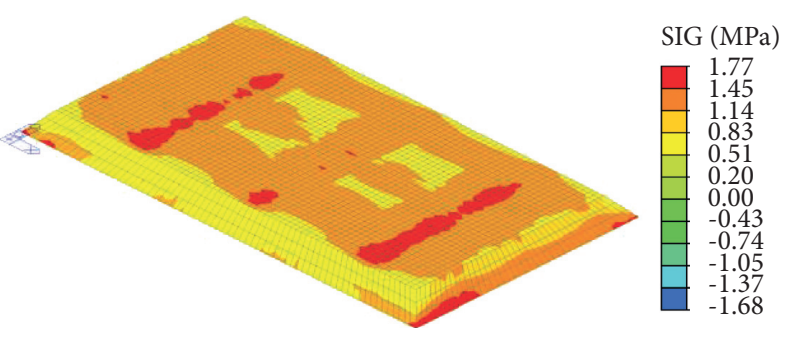

(b)

FIGURE 14: Cloud diagram of main tensile stress in the second layer of cap (unit: MPa). (a) Heating stage. (b) Cooling stage.

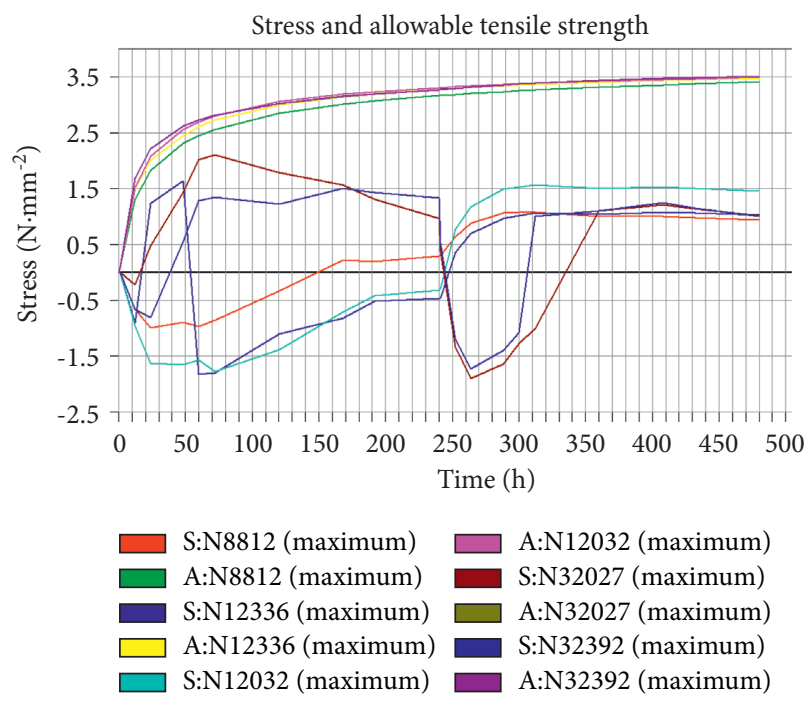

FIGURE 15: Time-history curve of main tensile stress at the second layer of cap.

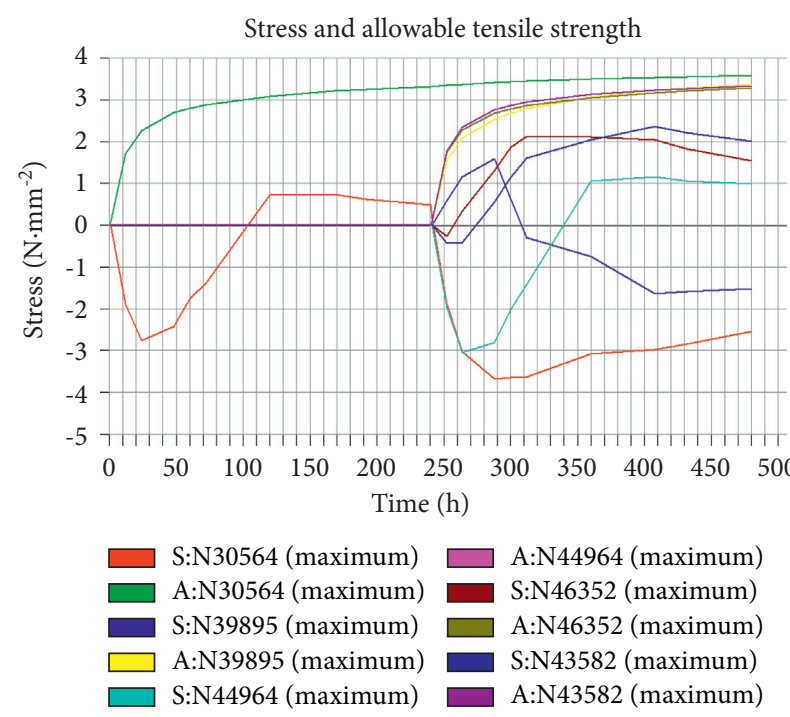

FIgURe 16: Cloud diagram of main tensile stress of tower (unit: $\mathrm{MPa})$. (a) Heating stage. (b) Cooling stage.

possible. The concrete pouring interval of the main tower cap is controlled at about 7 days, generally not more than 10 days. The actual pouring finish time of the first layer of the cap construction is at

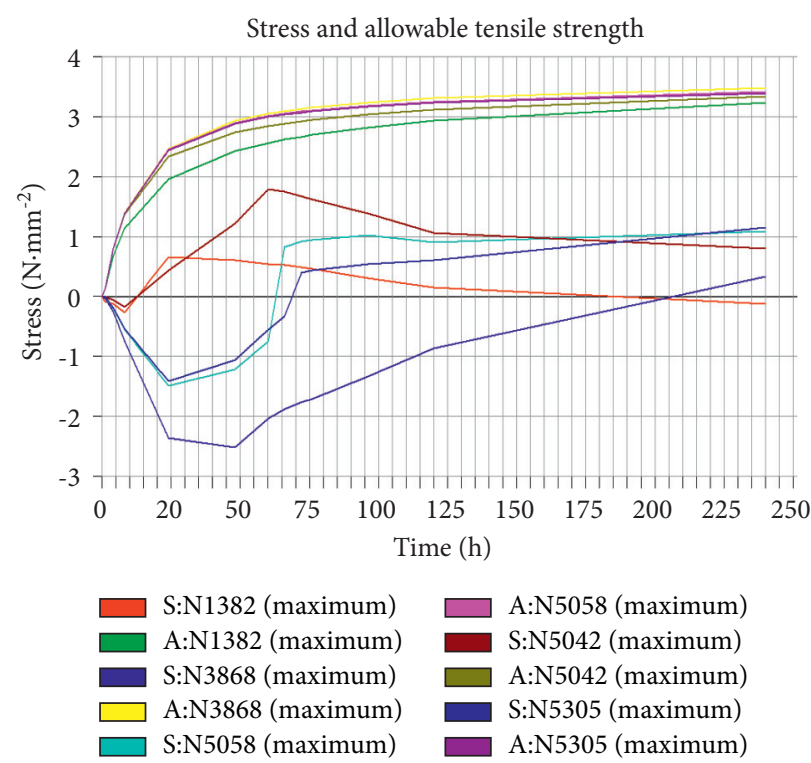

Figure 17: Time-history curve of tower principal tensile stress.

20:00 on May 29, 2020. The second pouring time is at 10:00 on June 10,2020 , and the interval is within 10 days.

\section{Temperature Control Standard}

According to the relevant requirements of the current codes and regulations, and in combination with the actual situation of the construction of the tower base of Jinsha River Bridge, the main temperature control standards are drawn up in Table 5.

It is an important measure for temperature control of mass concrete to reduce the temperature of concrete entering mold as much as possible. Under the condition of concrete fit ratio and heat transfer boundary condition, the higher the temperature of concrete entering mold is, the higher the temperature peak value is, and the greater the temperature difference between inside and outside concrete, temperature deformation, and temperature stress are. In addition, the higher the injection temperature, the faster the hydration reaction rate of concrete, most of the hydration heat will be released in the initial stage of concrete pouring, strength and elastic modulus will also increase, adverse to temperature control. 
TABLE 5: Temperature control standard of cap.

\begin{tabular}{|c|c|c|c|}
\hline $\begin{array}{l}\text { Serial } \\
\text { number }\end{array}$ & Temperature control item & $\begin{array}{l}\text { Control } \\
\text { standard }\end{array}$ & Basis \\
\hline 1 & Pouring temperature of concrete & $\leq 26^{\circ} \mathrm{C}$ & $\begin{array}{c}\text { Construction conditions and calculation results of } \\
\text { temperature control }\end{array}$ \\
\hline 2 & Maximum internal temperature of concrete & $\leq 65^{\circ} \mathrm{C}$ & \\
\hline 3 & $\begin{array}{c}\text { Temperature difference between inside and outside of } \\
\text { concrete (including equivalent temperature of } \\
\text { concrete shrinkage) }\end{array}$ & $\leq 20^{\circ} \mathrm{C}$ & $\begin{array}{l}\text { 《Code for construction of mass concrete 》(GB 50496- } \\
2018 \text { ); 《code for construction of concrete structures》 }\end{array}$ \\
\hline 4 & Cooling rate inside casting concrete & $\leq 2.0^{\circ} \mathrm{C} / \mathrm{d}$ & (GB50666-2011); calculation results of temperature \\
\hline 5 & $\begin{array}{l}\text { Temperature difference between surface and } \\
\text { atmosphere of pouring concrete }\end{array}$ & $\leq 20^{\circ} \mathrm{C}$ & \\
\hline 6 & $\begin{array}{l}\text { Temperature difference between inlet and outlet of } \\
\text { cooling water }\end{array}$ & $\leq 10^{\circ} \mathrm{C}$ & $\begin{array}{l}\text { 《Technical code for construction of highway bridges } \\
\text { and culverts》(JTG/TF50-2011) }\end{array}$ \\
\hline 7 & $\begin{array}{l}\text { The temperature difference between the cooling water } \\
\text { and the inside concrete when the water is first supplied } \\
\text { or resupplied after interruption }\end{array}$ & $\leq 25^{\circ} \mathrm{C}$ & $\begin{array}{l}\text { 《Technical specification for temperature crack control } \\
\text { of mass concrete in water transport engineering》 (JTS }\end{array}$ \\
\hline 8 & $\begin{array}{c}\text { Temperature difference between curing water and } \\
\text { concrete surface }\end{array}$ & $\leq 15^{\circ} \mathrm{C}$ & $202-1-2010)$ \\
\hline
\end{tabular}

According to the calculation results, the order of the influence of various raw materials on the temperature of concrete is coarse aggregate $>$ fine aggregate and water$>$ cement and fly ash. Therefore, reducing the temperature of coarse aggregate and mixing water is the most effective way to reduce the concrete temperature of out-of-machine. The concrete temperature can be reduced by $0.40^{\circ} \mathrm{C}$ and $0.24^{\circ} \mathrm{C}$ for each decrease of coarse aggregate and mixing water by $1{ }^{\circ} \mathrm{C}$.

It is necessary to measure the temperature of water, cement, aggregate, and admixture before concrete mixing and estimate the temperature of concrete after mixing according to the empirical formula. If it cannot meet the requirements of the temperature of concrete entering mold, some measures should be taken such as adding ice and precooling of aggregate for trial mixing until the requirements are met.

\section{Temperature Control Effect}

\subsection{Temperature Monitoring Scheme}

6.1.1. Temperature Monitoring Content. Temperature monitoring mainly includes temperature measurement of environmental system and temperature field measurement of concrete. Temperature measurement of environmental system includes atmospheric temperature and inlet and outlet temperature of cooling water. Atmospheric temperature measurement includes the analysis of seasonal temperature difference, daily temperature, and cold wave. Select representative cooling water pipes and install temperature sensors in the inlet and outlet of water pipes and the middle of straight line section to measure the temperature of cooling water.

6.1.2. Layout of Concrete Temperature Measuring Points. The pipes of cooling water are made of Q235B with diameter of $32 \mathrm{~mm}$ and wall thickness of $2.5 \mathrm{~mm}$. The bending part of the pipe is pretreated with cold bending. The pipe is closely connected with silk buckle and raw tape.

The layout principle of temperature monitoring point of cap: the actual distribution and temperature field characteristics of cooling water pipe in concrete should be fully considered, and the corresponding specification requirements should be met:

(i) According to the characteristics of structural symmetry, half of the structure is selected as the main test area, and the other half of the key measurement points are arranged

(ii) Two temperature measuring elements are buried at important measuring points to prevent damage and ensure data integrity

(iii) Fully consider the distribution law of temperature field, as well as the position of cooling water pipe, water inlet and outlet

(iv) Fully reflect the evaluation of temperature control indicators

The specific arrangement of measuring points on the cap is shown in Figure 18. The final arrangement of measuring points may need to be adjusted appropriately according to the construction scheme and calculation results. Numbering rules of temperature measuring points: measuring points along the bridge are $X_{n}-(1 \sim N)$, such as $X_{2}-(1 \sim N)$ in the second layer. Cross bridge direction measurement point is $Y_{n}-(1 \sim N)$ such that the second layer is $Y_{2}-(1 \sim N)$. The central measurement point is $Z_{n}-0$.

6.2. Temperature Monitoring Results. Before the concrete is put into the mold, check whether the instrument is damaged after being buried and observe the temperature in the concrete. Automatic temperature acquisition instrument is adopted to collect temperature data once per hour. According to the predicted calculation results of temperature field and stress field, combined with the comparative analysis of 


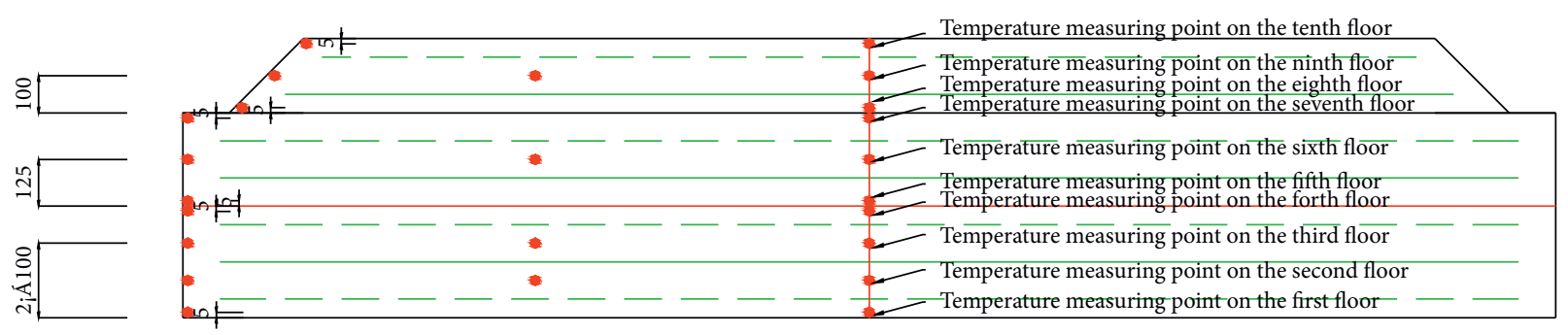

(a)
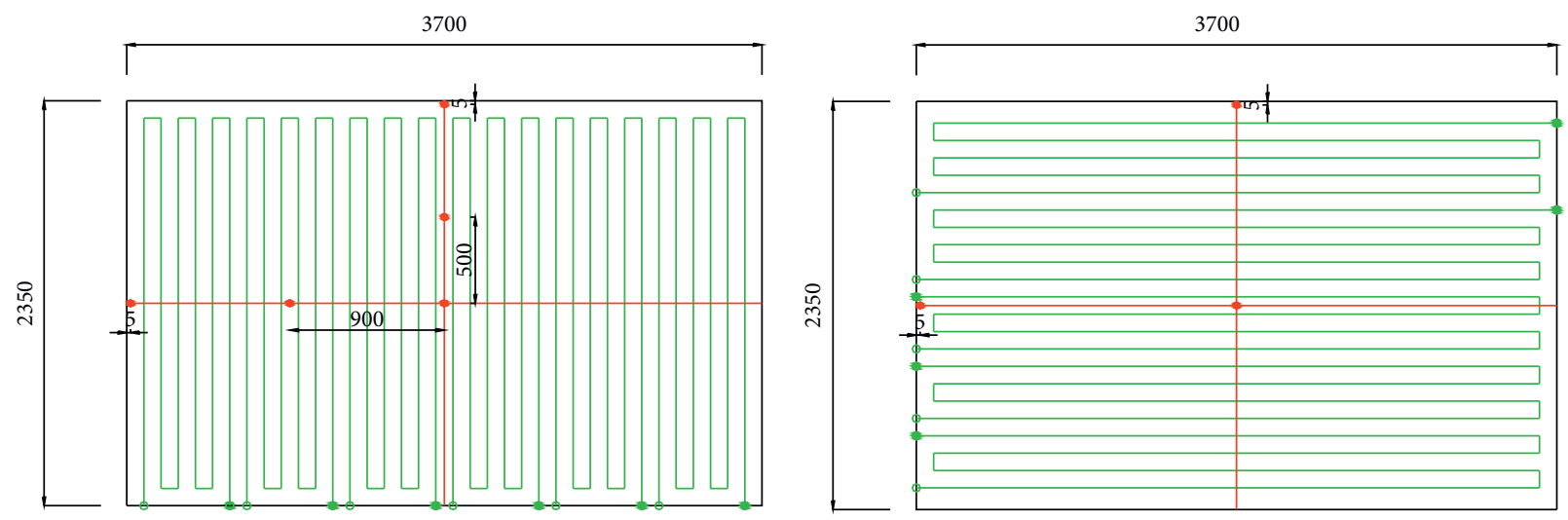

(b)
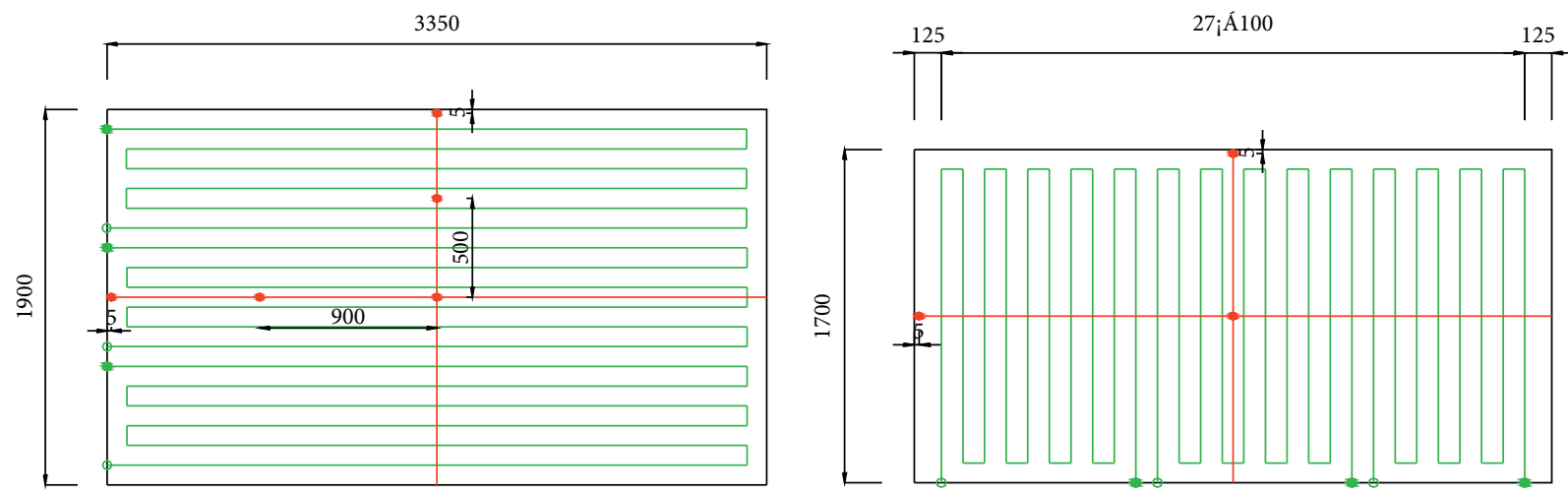

(c)

FigURE 18: Layout of temperature measuring points. (a) Elevation layout of temperature measuring point of cap. (b) Floor plan of temperature measuring point of cap. (c) Layout of temperature measuring point of tower.

monitoring results, the termination time of measurement is determined. Ambient air temperature and inlet and outlet temperature of cooling water are monitored synchronously with the temperature of concrete, as shown in Figures 19 and 20. The corresponding data are shown in Table 6. The insulation measures proposed in the numerical simulation of temperature control are the same as those in the construction.

The monitoring data of the first pouring concrete of the cap was collected from May 29, 2020, to June 16, 2020 (there was a lack of measurement data four times due to power outages in the middle), and the monitoring data of the second pouring of the cap was collected from June 10, 2020, to June 17, 2020.

The measured results show that the measured values of the first and second pouring of the temperature control project meet the requirements of the specification. The data show that the measures of this project can achieve good temperature control effect. 


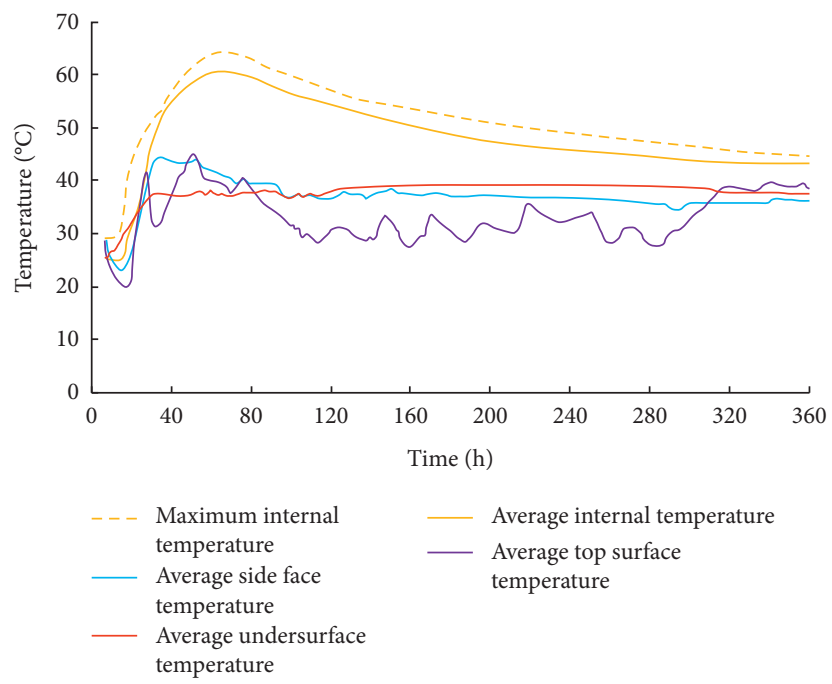

FIGURE 19: Monitoring results of the first pouring temperature of cap.

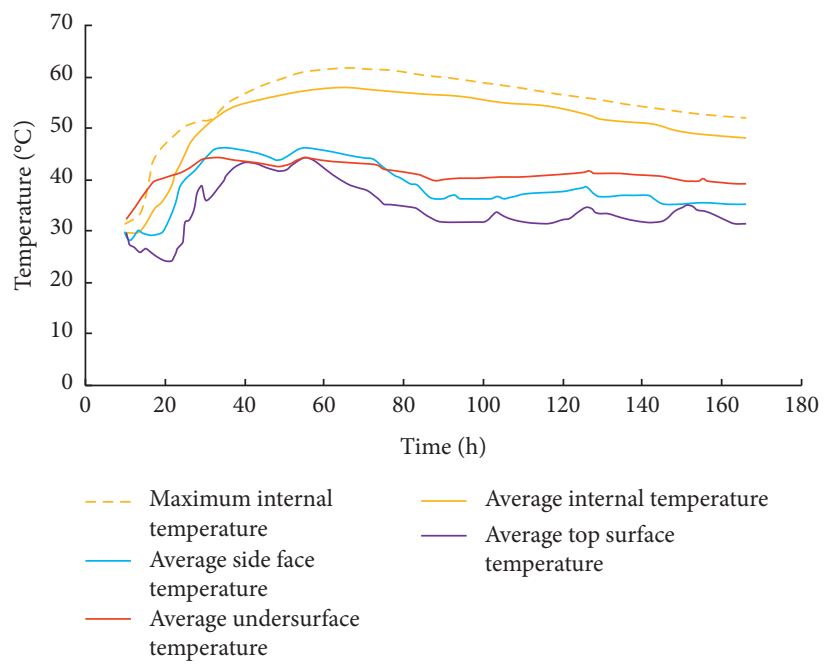

FIGURE 20: Monitoring results of second pouring temperature of cap.

TABLE 6: Analysis of measured results of cap temperature.

\begin{tabular}{|c|c|c|c|c|}
\hline $\begin{array}{l}\text { Serial } \\
\text { number }\end{array}$ & Temperature control item & $\begin{array}{c}\text { Control } \\
\text { standard }\end{array}$ & $\begin{array}{l}\text { Measured value of } \\
\text { first pouring }\left({ }^{\circ} \mathrm{C}\right)\end{array}$ & $\begin{array}{r}\text { Measured value of } \\
\text { second pouring }\left({ }^{\circ} \mathrm{C}\right)\end{array}$ \\
\hline 1 & Temperature of pouring concrete & $\leq 26^{\circ} \mathrm{C}$ & $25 \sim 30$ & $24 \sim 28.5$ \\
\hline 2 & Maximum temperature of internal concrete & $\leq 65^{\circ} \mathrm{C}$ & 64.5 & 61.6 \\
\hline 3 & $\begin{array}{l}\text { Temperature difference between the inner surface of concrete } \\
\text { pouring body (including equivalent temperature of concrete } \\
\text { shrinkage) }\end{array}$ & $\leq 28^{\circ} \mathrm{C}$ & 26.6 & 24.6 \\
\hline 4 & The rate of cooling of inside concrete & $\leq 2.0^{\circ} \mathrm{C} / \mathrm{d}$ & 2.1 & 1.98 \\
\hline 5 & $\begin{array}{l}\text { Temperature difference between surface of concrete and } \\
\text { atmosphere }\end{array}$ & $\leq 20^{\circ} \mathrm{C}$ & 16.1 & 17.1 \\
\hline 6 & $\begin{array}{l}\text { Temperature difference between inlet and outlet of cooling } \\
\text { water }\end{array}$ & $\leq 10^{\circ} \mathrm{C}$ & - & 9.8 \\
\hline 7 & $\begin{array}{l}\text { The temperature difference between the cooling water and the } \\
\text { inside concrete when the water is first supplied or resupplied } \\
\text { after interruption }\end{array}$ & $\leq 25^{\circ} \mathrm{C}$ & 24.8 & - \\
\hline 8 & $\begin{array}{l}\text { Temperature difference between curing water and concrete } \\
\text { surface }\end{array}$ & $\leq 15^{\circ} \mathrm{C}$ & True & True \\
\hline
\end{tabular}




\section{Conclusions}

(1) The internal temperature of concrete reached the peak value 33 hours later after the first pouring while reached the peak value 41 hours later after the second pouring. The peak value time appeared earlier than the simulated peak time, indicating that temperature monitoring and temperature control measures are very necessary.

(2) The 3D models in Figures 4 and 5 are established by MIDAS/civil finite element software. The simulated temperature peak value of the first pouring is $10.1^{\circ} \mathrm{C}$ lower than the measured value, and the simulated temperature peak value of the second pouring is $6.2^{\circ} \mathrm{C}$ lower than the measured value, which is mainly caused by the high temperature of pouring concrete.

(3) In the whole casting process, the temperature difference between inlet and outlet of cooling water is small can meet the requirements of $10^{\circ} \mathrm{C}$. But around the time when the internal temperature reaches the peak, the inlet and outlet temperature difference is large; the measured values are up to $25.1^{\circ} \mathrm{C}$. It is recommended to adopt full water storage heat preservation and maintenance system, strengthen the regulation of reservoir water temperature, according to the change of temperature day and night. The temperature difference between water storage and concrete surface is controlled at about $10^{\circ} \mathrm{C}$.

(4) There is time lag effect in controlling the cooling rate of concrete pouring body by adjusting the temperature or flow of cooling water. Comparatively speaking, it is easy to control the temperature of concrete entering mold. The measured results show that the measured values of the first and second pouring of the temperature control project meet the requirements of the specification. The data show that the measures of this project can achieve good temperature control effect.

\section{Data Availability}

All data used to support the findings of this study are included within the article, and there are not any restrictions on data access.

\section{Conflicts of Interest}

The authors declare that they have no conflicts of interest.

\section{Acknowledgments}

This work was supported by the excellent teaching team of "Qinglan Project" in Jiangsu Universities, "Innovative Teaching Team of Road and Bridge Engineering Technology Specialty" (Teacher Letter Su (2021) no. 11) project.

\section{References}

[1] J. H. Gao and S. L. Liu, "Analysis of thermal theory calculation and temperature control measures for mass concrete construction," Construction Machinery, no. 2, pp. 52-58, 2019.

[2] Z. Zhang, J. Bai, Y. Chen, and S. Yan, "An innovative approach for gob-side entry retaining in highly gassy fully-mechanized longwall top-coal caving," International Journal of Rock Mechanics and Mining Sciences, vol. 80, pp. 1-11, 2015.

[3] H. Wan and Z. H. Tan, "Anti-crack construction technology of mass concrete for main bridge cap of south dongting super large bridge," Journal of China \& Foreign Highway, vol. 37, no. 3, pp. 141-144, 2017.

[4] J. F. Yuan, J. D. Zhang, and D. Liu, "Analysis on hydration heat and temperature control measures of high strength concrete block 0\# of long-span continuous box girder bridge," Journal of China \& Foreign Highway, vol. 39, no. 5, pp. 97-101, 2019.

[5] Y. He, J. L. He, P. Yu, B. Zhang, and X. Fu, "Study on temperature control of mass concrete for tower pile cap," Journal of Railway Science and Engineering, vol. 17, no. 2, pp. 372-378, 2020.

[6] S. C. Jin, W. Y. Xu, and Y. Y. Huang, "Study on the temperature control measures for pile cap mass concrete constructed layer by layer in winter," Railway Engineering, vol. 59, no. 11, pp. 55-58, 2019.

[7] G. A. Zhu, L. M. Dou, Z. L. Li, W. Cai, K. Yong, and J. Li, "Mining-induced stress changes and rock burst control in a variable-thickness coal seam," Arabian Journal of Geosciences, vol. 5, no. 9, pp. 365-376, 2016.

[8] M. Qiao, "Research and application of key technologies of temperature control in mass concrete construction of pile cap of a super-large bridge," Highway Engineer, vol. 44, no. 5, pp. 135-141, 2019.

[9] Y. X. Yang, H. X. Zhou, J. L. Ma et al., "Study on temperature control and distribution of mass concrete cap," Bulletin of the Chinese Ceramic Society, vol. 38, no. 5, pp. 1497-1509, 2019.

[10] Z. Yang, C. Liu, S. Tang, L. Dou, and J. Cao, "Rock burst mechanism analysis in an advanced segment of gob-side entry under different dip angles of the seam and prevention technology," International Journal of Mining Science and Technology, vol. 28, no. 6, pp. 891-899, 2018.

[11] Y. C. Wang, Y. Hua, and C. Zhang, "Influence of different temperature control measures on crack resistance of large-size concrete structure," Journal of Highway and Transportation Research and Development, vol. 36, no. 3, pp. 109-116, 2019.

[12] D. D. Zhang and Z. H. Yang, "Research on temperature control of large volume concrete construction by using space cooling net," Highway Engineer, vol. 42, no. 3, pp. 282-285, 2017.

[13] J. Z. Li and Y. L. Wang, "Study on dynamic curing design of pile cap massive concrete of Shanghai-Nantong Yangtze river bridge," Railway Standard Design, vol. 60, no. 2, pp. 93-99, 2016.

[14] Z. Q. Yang, C. Liu, F. S. Li, L.-m. Dou, G.-w. Li, and D.-w. Wang, "The mechanism and application of highpressure water jet technology to prevent compound dynamic disaster," Arabian Journal of Geosciences, vol. 14, no. 13, pp. 1-20, 2021.

[15] Z.-Q. Yang, C. Liu, G.-A. Wang, G.-W. Li, and F.-S. Li, "Structural characteristics analysis of overlying rocks and prevention measures with a long-wall face passing across abandoned roadways: a case study," Shock and Vibration, vol. 2021, Article ID 6665341, 15 pages, 2021. 
[16] J. He, Research of Mining Dynamic Loading Effect and its Induced Rock Burst in Coal Mine, China University of Mining and Technology, Xuzhou, China, 2013.

[17] G. C. Zhang, L. J. Chen, Z. J. Wen et al., "Squeezing failure behavior of roof-coal masses in a gob-side entry driven under unstable overlying strata," Energy Science \& Engineering, vol. 8, pp. 1-14, 2020.

[18] M. Hu, W. Zhao, Z. Lu, J. Ren, and Y. Miao, "Research on the reasonable width of the waterproof coal pillar during the mining of a shallow coal seam located close to a reservoir," Advances in Civil Engineering, vol. 2019, Article ID 3532784, 14 pages, 2019. 